\title{
Visual strength grading of Argentinean Eucalyptus grandis
}

\section{Strength, stiffness and density profiles and corresponding limits for the main grading parameters}

Published online: 9 December 2003

(C) Springer-Verlag 2003

\begin{abstract}
The present paper reports the results of an investigation regarding the design of a method for visually grading sawn timber of Argentinean Eucalyptus grandis. An empirical research project with four samples of beams and one sample of boards subjected to bending, one sample of boards subjected to tension and one sample of specimens subjected to compression, was carried out. The results obtained with specimens in structural sizes show the influence of the more important strength and stiffness reducing growth characteristics and allow to analyse different strength, stiffness and density profiles in comparison with the international strength class system established in the European standard EN 338. The research also reveals particularities for this timber species as the high ratio of modulus of elasticity and strength to density, in comparison with other deciduous species, among others.
\end{abstract}

\section{Visuelle Festigkeitssortierung von Eucalyptus grandis aus Argentinien \\ Festigkeits-, Steifigkeits- und Rohdichteprofile und zugehörige Grenzwerte der Sortierparameter}

Zusammenfassung Dieser Beitrag fasst die Ergebnisse einer Studie zusammen, in der die Möglichkeiten einer visuellen Festigkeitssortierung von Eucalyptus grandis aus Argentinien untersucht wurden. Die Untersuchung umfasste vier Teilstichproben mit Kanthölzern und eine

\section{J. C. Piter}

Departamento de Ingeniería Civil,

Facultad Regional Concepción del Uruguay,

Universidad Tecnológica Nacional, Ing. Pereira 676,

(E3264BTD) C. del Uruguay, Entre Ríos, Argentina

\section{R. L. Zerbino}

Departamento de Ingeniería Civil, Facultad de Ingeniería, Universidad Nacional de La Plata,

48 y 115, (1900) La Plata, Buenos Aires, Argentina

\section{H. J. Blaß (-}

Lehrstuhl für Ingenieurholzbau und Baukonstruktionen, Universität Karlsruhe, 76128 Karlsruhe, Germany

e-mail: hans.blass@holz.uka.de
Teilstichprobe mit Brettern in Biegeversuchen und jeweils eine Teilstichprobe mit Zug- bzw. Druckprüfkörpern. Die Ergebnisse der Versuche mit Prüfkörpern in Bauholzabmessungen zeigen den Einfluss der wichtigsten visuellen Sortierparameter und erlauben die Einteilung von Bauholz aus Eucalyptus grandis in unterschiedliche Festigkeitsklassen nach EN 338. Die vorliegende Studie zeigt darüber hinaus besondere Eigenschaften dieser Laubholzart wie das hohe Verhältnis von Elastizitätsmodul und Festigkeit zur Rohdichte.

\section{Introduction}

Eucalyptus grandis, which is mainly cultivated in the Mesopotamian provinces of Entre Ríos and Corrientes, is one of the most important renewable species cultivated in Argentina (INTA 1995). Up to the present neither a method for strength grading this timber for structural purposes has been developed nor test series with specimens in structural sizes were carried out. As a consequence, the characteristic values of its mechanical properties are not well known and it is not considered a reliable material. Since the use of structural sawn timber is based on its characteristic strength and stiffness values, and wood exhibits great variations in quality, economic and technical reasons account for the necessity of a grading method based on a piece by piece inspection (Glos 1995). There are currently many different visual and machine strength grading standards and a growing tendency towards the utilisation of a strength class system as that established in the European standard EN 338 (1996).

One of the advantages of visual strength grading in comparison with machine strength grading is that it doesn't require expensive equipment. For a country with no tradition connected with grading processes as Argentina, the simplicity of the rule to be applied is also of great importance. However, for introducing a visual strength grading method in the international system, it should meet the minimum general requirements for strength grading 
rules which are laid down in the European standard prEN 14081-1 (2000), and the method for measuring the features described in the European standard EN 1310 (1997). Bending strength and stiffness are considered to be the most important mechanical properties in this system, and all other strength and stiffness values can be derived from either bending strength, modulus of elasticity or density. In particular, mechanical properties for boards in tension parallel to the grain are considered to be important for calculating the characteristic values of glued laminated timber according to EN 1194 (1999). The procedures for determining the fundamental physical and mechanical properties are established in the European standard EN 408 (1996), and the method for calculating the corresponding characteristic values in EN 384 (1996).

The strength reducing characteristics for visual grading considered in prEN 14081-1 (2000), are: knots, slope of grain, density and rate of growth, and fissures, but it specifies that additional criteria may be listed and limited. Knots are considered the most important defect affecting mechanical properties (Hoffmeyer 1995), and high correlation coefficients between knots and strength have been found for both softwoods (Hermoso Prieto 2001) and hardwoods (Glos \& Lederer 2000). Due to its importance, dimensions of knots have been considered in different ways by many researchers and standards, as is the case of knot ratio expressed in relation to the cross sectional area or in relation to the width or thickness of the timber (American Society for Testing and Materials 1999; Glos \& Lederer 2000; Standards Australia 2000). Slope of grain exhibits generally a lower correlation with strength than knots, and density, which can be evaluated through the width of growth rings in most softwoods and in some hardwoods, shows a medium correlation with strength (Glos 1995; Hoffmeyer 1995). Fissures may affect the strength according to type, size and location in the piece, and their lengths are limited in prEN 14081-1 (2000).

Knots may be associated with internal decayed branch stubs in eucalyptus, although they appear sound and the lower branches may soon die because of insufficient availability of light, as is the case of Eucalyptus grandis (Hillis 1978). Slope of grain is considered to be less important in eucalyptus than in coniferous although severe inclination from the vertical, and spiral, as well as interlocked grain have been reported for different species (Hillis 1978). For the case of Argentinean Eucalyptus grandis, usually straight and occasionally interlocked grain was found (INTA 1995). Growth rings, which exhibit a great variability within the eucalyptus, and also within species, between samples and specimens, are vaguely discernable and sometimes absent in the case of Eucalyptus grandis (Dadswell 1972). Fissures, normally associated with shrinkage and drying defects, show a large variation in eucalyptus, Eucalyptus grandis being one of the species which exhibits less problems (Hillis 1978; INTA 1995). The central zone is characterised by wood of reduced strength and stiffness for eucalyptus and other hardwoods due to minute failures in the wall fibres, among other causes (Hillis 1978) and, consequently, the presence of timber adjacent to or including the pith is limited in the Australian standard 2082 (2000). Better strength and stiffness values for boards of Uruguayan Eucalyptus grandis distant of the pith, than for others adjacent to it, were reported by Pérez del Castillo (2001). The presence of kino veins was reported as a particular source of degradation in eucalyptus timber, exhibiting a large variation from tree to tree, but only in cases of large veins affecting its structural properties (Hillis 1978). Dadswell (1972) described the presence of kino in Eucalyptus grandis in the category of less amount, down to very sparse, or absent. No important biological affections, as decay, fungal or insect damages, were found in Argentinean Eucalyptus grandis (INTA 1995).

The aim of this paper is to present and discuss the results of an investigation regarding the visual parameter influence on the mechanical properties of Argentinean Eucalyptus grandis, and to propose a simple method for visually grading this sawn timber species, with strength, stiffness and density profiles and their correspondent limits for the parameters. Additionally, to present and discuss the relationships found between bending strength and stiffness, and the tension and compression ones.

\section{Materials and methods}

In the framework of a timber strength grading project organised by the Argentinean Timber Technological Network (RITIM), and carried out at the Argentinean Universidad Nacional de La Plata and Universidad Tecnológica Nacional, in co-operation with the German Universität Karlsruhe, test samples of 1984 Eucalyptus grandis were obtained from Virasoro, Corrientes, and of 1981 Eucalyptus grandis from Concordia, Entre Ríos. They are the main provenance for this species in Argentina. Nine trees of each provenance were used.
Table 1 Test samples. $n$ is the number of specimens

Tabelle 1 Teilstichproben. $n$ ist die Anzahl der Prüfkörper

\begin{tabular}{llcc}
\hline Sample & Static Test & $\begin{array}{l}\text { Sample size } \\
(n)\end{array}$ & $\begin{array}{l}\text { Nominal size of specimens } \\
(\mathrm{mm})\end{array}$ \\
\hline 1 & Bending (edgewise) & 50 & $50 \times 50 \times 1000$ \\
2 & Bending (edgewise) & 50 & $50 \times 75 \times 1500$ \\
3 & Bending (edgewise) & 50 & $50 \times 100 \times 2000$ \\
4 & Bending (edgewise) & 50 & $50 \times 150 \times 3000$ \\
5 & Bending (flatwise) & 149 & $100 \times 25 \times 500$ \\
6 & Tension parallel to the grain & 150 & $100 \times 25 \times 1200$ \\
7 & Compression parallel to the grain & 50 & $50 \times 75 \times 300$ \\
\hline
\end{tabular}


With the aim of obtaining representative samples (see Table 1) regarding the quality variation in timber, the specimens were randomly selected and taken from different locations in the log. After a period of air-drying under protected external conditions, they were surfaced and conditioned in a room at $25^{\circ} \mathrm{C}$ temperature and $65 \%$ relative humidity.

Actual dimensions and measurements for each test piece were taken after conditioning in normal climate, and made to an accuracy of $1 \%$. Location and measures of knots in all faces of each specimen were registered, and knot ratio was expressed according to four different criteria, all suitable for applying to both boards and beams: i) relation of the width of the largest knot measured between lines enclosing it and parallel to the edges of the piece, and the width or thickness of the surface on which it appears. For edge knots the lower value was considered of the surfaces on which it showed up (hereafter K), ii) projection of the largest knot on the cross section in relation to the cross section area (KAR 1), iii) largest area of the projection of all knots in a cross section divided by the cross section area, without overlapping (KAR 2), iv) the same criterion as the preceding one, but applied to the sum of all knots in any $150 \mathrm{~mm}$ of length of the specimen (KAR 3). No distinctions were made between different types of knots, and those with diameters less than $5 \mathrm{~mm}$ were ignored. General slope of grain was determined on all faces of each piece by means of a swivel-handled scribe and expressed as a ratio, disregarding inclinations less than 1/ 14 and local deviations. Growth rings were registered along the longest radial line at both ends of each piece, and rate of growth was expressed as the average width of growth rings, ignoring the first $25 \mathrm{~mm}$ from the pith, if it was present. Fissures were located, described and measured in all faces of each specimen. The presence of pith was registered at both ends and on all faces of each piece. Kino veins and biological characteristics as decay, fungal and insect damage, were registered on all faces of each specimen.

After physical measurements and features were taken and recorded, static tests in bending, tension and compression were carried out according to the procedures of EN 408 (1996). A loading machine Shimadzu UH $1000 \mathrm{kN}$, capable for applying loads with adequate rate of movement of the loading-head and accuracy of $1 \%$ was used for all static tests. For bending, specimens were placed symmetrically on the supports and loaded at onethird span length, with their weakest section located in the central zone. With the aim to better study the influence of defects on strength, specimens were placed with the largest growth defects in the tension zone. Deformations were registered at the centre of the span and at the centre of the tension zone for determining the global modulus of elasticity, by means of an extensometer Somet, capable of registering $0.01 \mathrm{~mm}$. Strength $\left(\mathrm{f}_{\mathrm{m}}\right)$ and global modulus of elasticity $\left(\mathrm{E}_{\mathrm{m}, \mathrm{g}}\right)$ were calculated using the standard solution. Tension tests were carried out providing a clear length between machine grips equal to 9 times the width of each piece. Deformations were measured over a length of 5 times the width and containing the weakest cross section. Two extensometers Kafer, attached at diagonally opposite points to minimise the effects of distortion and capable of registering $0.001 \mathrm{~mm}$ were used. Specimens for compression tests were prepared with a length equal to 6 times the thickness. Deformations were measured over a length of 4 times the thickness with two extensometers as was explained for tension tests. Tensile $\left(\mathrm{f}_{\mathrm{t}, 0}\right)$ and compression $\left(\mathrm{f}_{\mathrm{c}, 0}\right)$ strength, as well as modulus of elasticity in tension $\left(\mathrm{E}_{\mathrm{t}, 0}\right)$ and compression $\left(\mathrm{E}_{\mathrm{c}, 0}\right)$ parallel to the grain were determined using the standard solution.

Moisture content and density $(\rho)$ were calculated according to the procedures of ISO 3130 (1975) and ISO 3131 (1975) respectively, using a clear full cross section taken from the test specimen after the static test. The characteristic strength, stiffness and density values were determined according to EN 384 (1996).

\section{Results and discussion}

The main results for the visual features corresponding to samples subjected to bending tests are summarised in Table 2. The mean value of moisture content for the 349 specimens was $14.8 \%$. In many cases it was impossible to distinguish the annual rings, coinciding with results of other investigations with this timber species (Dadswell 1972) and, consequently, the average width of growth rings was disregarded as a visual parameter for this purpose.

Knot ratio expressed according to criterion $\mathrm{K}$ exhibits generally greater mean and maximum values but smaller coefficient of variation than the other ones. Differences between mean values calculated according to the four criteria are higher for beams than for boards, and specimens of Sample 1, with the smallest cross-sectional dimensions for beams, present the greatest mean value in all cases. The mean value of KAR 2 for all samples is $6 \%$ greater than for KAR 1, and this difference between KAR 3 and KAR 2 is $23 \%$. The same relation for boards are $8 \%$ and $19 \%$, respectively, indicating a similar presence of knot groupings both in boards and beams.

Only 23 specimens $(7 \%)$ with slope of grain greater than $1 / 14$ were found, with similar percentage in all samples. A particular analysis shows a maximum slope of grain of 1/9 for only one specimen and a value of $1 / 10$ in four cases, which is consistent with results of other investigations (Hillis 1978; INTA 1995) and indicates that this feature can be disregarded as a visual parameter for this study. A total of 91 (26\%) specimens presented fissures exceeding the limits established in prEN 14081-1 (2000) for strength classes above C18 with greater values for beams than for boards. Boards of Sample 5 show the minimum value of $9 \%$, and with the only exception of Sample 2, the larger the beam sizes the higher the percentage, with maximum values of $52 \%$ and $54 \%$ for Sample 3 and 4 respectively. A detailed analysis indicates that $31(34 \%)$ specimens with this type of fissures were 
Table 2 Summary of results for the visual features corresponding to samples subjected to bending tests. (1) General slope of grain greater than $1 / 14$; (2) fissures larger than those permitted in prEN 14081-1 for strength classes $>\mathrm{C} 18$ and $\leq \mathrm{C} 18$; other values for features correspond to those registered in the central third

Tabelle 2 Visuelle Sortierparameter für die Teilstichproben der Biegeversuche. (1) Faserabweichung größer als $1 / 14$; (2) Risse größer als zulässig nach prEN 14081-1 für Festigkeitsklassen $>\mathrm{C} 18$ und $\leq \mathrm{C} 18$; andere Werte entsprechen denjenigen im mittleren Drittel

\begin{tabular}{|c|c|c|c|c|c|c|c|}
\hline & & $\begin{array}{l}\text { Sample } 1 \\
n=50\end{array}$ & $\begin{array}{l}\text { Sample } 2 \\
n=50\end{array}$ & $\begin{array}{l}\text { Sample } 3 \\
n=50\end{array}$ & $\begin{array}{l}\text { Sample } 4 \\
n=50\end{array}$ & $\begin{array}{l}\text { Sample } 5 \\
n=149\end{array}$ & $\begin{array}{l}\text { Whole } \\
n=349\end{array}$ \\
\hline K & $\begin{array}{l}\text { Min } \\
\text { Mean } \\
\text { Max } \\
\text { S }\end{array}$ & $\begin{array}{l}0 \\
0.43 \\
0.86 \\
0.21\end{array}$ & $\begin{array}{l}0 \\
0.33 \\
1.00 \\
0.24\end{array}$ & $\begin{array}{l}0 \\
0.41 \\
0.84 \\
0.21\end{array}$ & $\begin{array}{l}0.09 \\
0.34 \\
0.69 \\
0.16\end{array}$ & $\begin{array}{l}0 \\
0.30 \\
0.74 \\
0.17\end{array}$ & $\begin{array}{l}0 \\
0.34 \\
1.00 \\
0.19\end{array}$ \\
\hline KAR 1 & $\begin{array}{l}\text { Min } \\
\text { Mean } \\
\text { Max } \\
\text { S }\end{array}$ & $\begin{array}{l}0 \\
0.25 \\
0.83 \\
0.17\end{array}$ & $\begin{array}{l}0 \\
0.15 \\
0.70 \\
0.16\end{array}$ & $\begin{array}{l}0 \\
0.14 \\
0.33 \\
0.09\end{array}$ & $\begin{array}{l}0.02 \\
0.14 \\
0.31 \\
0.06\end{array}$ & $\begin{array}{l}0 \\
0.22 \\
0.56 \\
0.15\end{array}$ & $\begin{array}{l}0 \\
0.19 \\
0.83 \\
0.14\end{array}$ \\
\hline KAR 2 & $\begin{array}{l}\text { Min } \\
\text { Mean } \\
\text { Max } \\
\text { S }\end{array}$ & $\begin{array}{l}0.26 \\
0.83 \\
0.18\end{array}$ & $\begin{array}{l}0 \\
0.15 \\
0.70 \\
0.16\end{array}$ & $\begin{array}{l}0 \\
0.15 \\
0.45 \\
0.10\end{array}$ & $\begin{array}{l}0.02 \\
0.15 \\
0.38 \\
0.08\end{array}$ & $\begin{array}{l}0 \\
0.23 \\
0.64 \\
0.16\end{array}$ & $\begin{array}{l}0 \\
0.20 \\
0.83 \\
0.15\end{array}$ \\
\hline KAR 3 & $\begin{array}{l}\text { Min } \\
\text { Mean } \\
\text { Max } \\
\text { S }\end{array}$ & $\begin{array}{l}0 \\
0.31 \\
0.84 \\
0.20\end{array}$ & $\begin{array}{l}0 \\
0.19 \\
0.70 \\
0.18\end{array}$ & $\begin{array}{l}0 \\
0.21 \\
0.57 \\
0.13\end{array}$ & $\begin{array}{l}0.02 \\
0.19 \\
0.48 \\
0.10\end{array}$ & $\begin{array}{l}0 \\
0.28 \\
0.82 \\
0.19\end{array}$ & $\begin{array}{l}0 \\
0.25 \\
0.84 \\
0.18\end{array}$ \\
\hline Slope of grain $^{(1)}$ & $\mathrm{n}(\%)$ & $4(8)$ & $2(4)$ & $4(8)$ & $4(8)$ & $9(6)$ & $23(7)$ \\
\hline $\begin{aligned} \text { Fissures }^{(2)} & >\mathrm{C} 18 \\
& \leq \mathrm{C} 18\end{aligned}$ & $\begin{array}{l}\text { n }(\%) \\
\text { n }(\%)\end{array}$ & $\begin{array}{l}15(30) \\
12(24)\end{array}$ & $\begin{array}{r}10(20) \\
8(16)\end{array}$ & $\begin{array}{l}26(52) \\
20(40)\end{array}$ & $\begin{array}{l}27(54) \\
20(40)\end{array}$ & $\begin{array}{r}13(9) \\
5(3)\end{array}$ & $\begin{array}{l}91(26) \\
65(19)\end{array}$ \\
\hline Pith & $\mathrm{n}(\%)$ & $14(28)$ & $13(26)$ & $31(62)$ & $26(52)$ & $42(28)$ & $126(36)$ \\
\hline Kino veins & $\mathrm{n}(\%)$ & $12(24)$ & $13(26)$ & $10(20)$ & $26(52)$ & $23(15)$ & $84(24)$ \\
\hline Biological affections & n $(\%)$ & $0(0)$ & $2(4)$ & $0(0)$ & $1(2)$ & $0(0)$ & $3(1)$ \\
\hline Large defects & $\mathrm{n}(\%)$ & $0(0)$ & $1(2)$ & $1(2)$ & $1(2)$ & $0(0)$ & $3(1)$ \\
\hline
\end{tabular}

Table 3 Summary of the results for mechanical and density properties corresponding to samples subjected to bending tests

Tabelle 3 Mechanische Eigenschaften und Rohdichte für die Teilstichproben der Biegeversuche

\begin{tabular}{llccccc}
\hline & & Sample 1 & Sample 2 & Sample 3 & Sample 4 & Sample 5 \\
\hline $\mathrm{f}_{\mathrm{m}}\left(\mathrm{N} / \mathrm{mm}^{2}\right)$ & Min & 17.4 & 22.9 & 21.6 & 11.5 & 27.5 \\
& Mean & 42.4 & 53.6 & 43.9 & 40.3 & 62.1 \\
& Max & 80.3 & 115.1 & 65.2 & 67.2 & 111.4 \\
& $\mathrm{~S}$ & 12.3 & 16.8 & 10.2 & 13.1 & 15.8 \\
$\mathrm{E}_{\mathrm{m}, \mathrm{g}}\left(\mathrm{N} / \mathrm{mm}^{2}\right)$ & Min & 6800 & 7400 & 9000 & 8300 & 6100 \\
& Mean & 10900 & 12700 & 11800 & 12000 & 12200 \\
& Max & 14100 & 21500 & 14900 & 16400 & 19300 \\
& $\mathrm{~S}$ & 1860 & 2700 & 1560 & 1590 & 2440 \\
& Min & 419 & 444 & 430 & 431 & 421 \\
& Mean & 533 & 567 & 527 & 513 & 564 \\
& Max & 705 & 1094 & 732 & 587 & 739 \\
& $\mathrm{~S}$ & 76 & 110 & 72 & 37 & 65 \\
\hline
\end{tabular}

free of pith, whereas $60(66 \%)$ contained the growth centre. Fissures exceeding the limits for strength classes $\mathrm{C} 18$ and below were found in $65(19 \%)$ pieces. A total of $126(36 \%)$ specimens contained pith in the central zone, reaching in Sample 3 and 4 the highest values of $62 \%$ and $52 \%$ respectively, and coinciding with the great presence of fissures in specimens of these samples. Kino veins were found in $84(24 \%)$ specimens, exhibiting a great variation in size and shape. Only $3(1 \%)$ pieces presented light biological affections, confirming available data for the species (INTA 1995), and 3 (1\%) specimens exhibited large defects produced in the sawmill, as severe reduction of width or thickness.

The main results for mechanical and density properties are summarised in Table 3. Little data are available relating to strength and stiffness properties of this Argentinean timber species. Values of $73.1 \mathrm{~N} / \mathrm{mm}^{2}$ for modulus of rupture and of $9835 \mathrm{~N} / \mathrm{mm}^{2}$ for MOE were reported by INTA (1995) for a test series of air-dry Argentinean Eucalyptus grandis in small clear specimens determined according to ASTM D 143. Pérez del Castillo (2001) obtained a mean value of $54.0 \mathrm{~N} / \mathrm{mm}^{2}$ for modulus of rupture, and mean values ranging from $11200 \mathrm{~N} / \mathrm{mm}^{2}$ to $12600 \mathrm{~N} / \mathrm{mm}^{2}$ for MOE in a test series with boards in structural sizes of Uruguayan Eucalyptus grandis free of pith, determined according to ASTM D 198 with a moisture content of $12 \%$. Coefficient of variation for strength values are higher than those for modulus of elasticity in all samples, and are congruent with results reported by Glos \& Lederer (2000) for beech and oak timber in structural sizes and by Pérez del Castillo (2001) for Uruguayan Eucalyptus grandis. The mean bulk density compares well with published data for the species in Argentina (INTA 1995) and in Uruguay (Pérez del Castillo 2001), but is significantly lower than those 
reported by both Australian standards AS 2878-1986 (1986) and AS 2082-2000 (2000).

In order to evaluate the influence of the main visual parameters on strength, correlation between knot ratio and bending strength was investigated and expressed by correlation coefficients. For this purpose, all specimens were considered as a whole sample and strength values were corrected to a reference depth of $150 \mathrm{~mm}$ according to EN 384 (1996). Results indicate that strength and knot ratio are not highly related in this case, with values of $-0.32,-0.30,-0.30$ and -0.33 for the correlation between bending strength and K, KAR 1, KAR 2 and KAR 3 respectively, although the relationship is highly significant in all cases, with probability levels (p) less than 0.0005. Glos \& Diebold (1987) reported correlation coefficients of $-0.59,-0.53$ and -0.62 between bending strength and knot ratio measured in the same way as KAR1, KAR 2 and KAR 3 respectively, for a test series with beams of Picea abies in structural sizes. Johansson et al. (1992) found a correlation coefficient of -0.51 for knot ratio expressed in the same way as KAR 2, in a bending test series with specimens of Picea abies in structural sizes, whereas Glos \& Lederer (2000), applying the same criterion, reported values of -0.62 and -0.57 for oak and beech respectively. Both KAR 1 and KAR 2 show a value of -0.30 , which is congruent with the low difference of $6 \%$ found between the corresponding mean values as was presented in Table 2. KAR 3 exhibits a slightly better relationship than $\mathrm{K}$, but taking into account the simplicity of $\mathrm{K}$ in comparison with the other three criteria, hereafter knot ratio is expressed as $\mathrm{K}$ criterion, which is coincident with the one established in the Australian standard AS 2082 (2000) for measuring knot ratio in hardwoods.

In line with earlier suggestions regarding the affection of structural properties only by large kino veins (Hillis 1978), it was not possible to find a relationship between this feature and mechanical properties. Light biological attacks, that were found in only $1 \%$ of the specimens, may be disregarded for this purpose, and severe reduction of width or thickness, also present in $1 \%$ of the cases, must be restricted because it affects the strength and stiffness behaviour of the pieces.

Figure 1 shows the relatively poor correlation between knot ratio (K) and bending strength for the whole sample. In the same figure it is possible to appreciate separately both the specimens with and without pith and, consequently, the importance of this feature as reducing strength factor.

In order to discuss different strength, stiffness and density profiles and the corresponding limits for the main visual parameters, seven different options are presented in Table 4. For comparing each profile with those belonging to the strength class system established in EN 338 (1996), the lower 7.5th percentile of bending strength, the mean value for MOE, the lower 5th percentile and the mean value of bulk density were presented. It was calculated the 7.5th instead of the 5th lower percentile for strength, because specimens were placed with the greatest defects in the tension zone, disregarding the random criterion

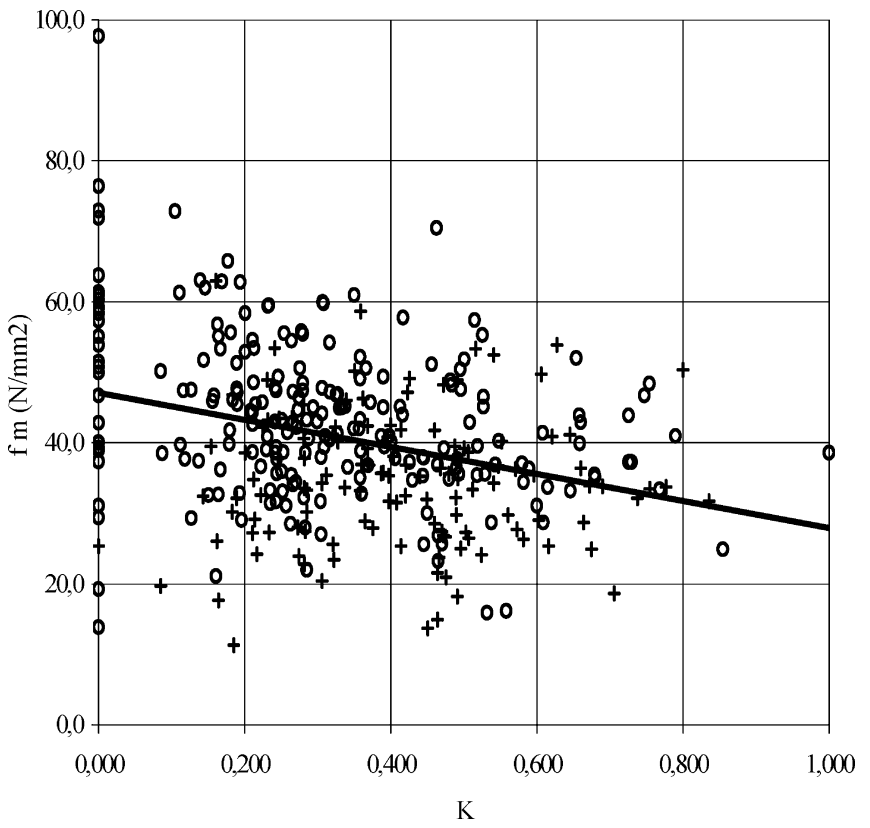

Fig. 1 Relationship between knot ratio $(\mathrm{K})$ and bending strength for 349 specimens of Samples 1 to 5. Correlation coefficient $=-0.32$. Linear regression equation: $f_{m}=-19.1 K+47.1$. ( $\bigcirc$ ): specimens free of pith; $(+)$ : specimens containing pith

Abb. 1 Zusammenhang zwischen Ästigkeit $(K)$ und Biegefestigkeit für 349 Prüfkörper der Teilstichproben 1 bis 5 . Korrelationskoeffizient $=-0.32$. Lineare Regressionsgleichung: $f_{m}=-19.1$ $\mathrm{K}+47.1$. ( $\bigcirc$ ): Prüfkörper ohne Markröhre; (+): Prüfkörper mit Markröhre

established in EN 384 (1996) (Glos \& Tratzmiller 1996; Glos \& Lederer 2000). Characteristic strength values were adjusted for sample size according to EN 384 (1996).

Profile b) shows values for strength and MOE 33\% (adjusted 38\%) and 17\% higher for specimens free of pith than for those containing it, respectively, with a low difference of $1 \%$ and $8 \%$ for density characteristic and mean value respectively. The yield in the best grade reaches $223(64 \%)$ specimens. These results are congruent with other reports of researchers and standards (Hillis 1978; Standards Australia 2000; Pérez del Castillo 2001) and confirm that the presence of pith, which also encloses most of the pieces with large fissures, significantly reduces the strength and stiffness properties of this timber species. Therefore it must be considered as an important parameter for designing a visual strength grading method. In profile c) specimens with both fissures exceeding the maximum length established in prEN 14081-1 (2000) for strength classes above $\mathrm{C} 18$ and severe reduction of width or thickness were added to the grade of less quality, lightly improving strength and MOE for the highest grade from $29.3 \mathrm{~N} / \mathrm{mm}^{2}$ to $31.1 \mathrm{~N} / \mathrm{mm}^{2}$ (adjusted from $26.4 \mathrm{~N} /$ $\mathrm{mm}^{2}$ to $28.0 \mathrm{~N} / \mathrm{mm}^{2}$ ) and from $13400 \mathrm{~N} / \mathrm{mm}^{2}$ to $13500 \mathrm{~N} /$ $\mathrm{mm}^{2}$ respectively. The low difference found between values of profiles c) and b) is congruent with the high correlation found between the presence of pith and fissures. The values for density in profile c) are similar 
Table 4 Strength, stiffness and density profiles with the corresponding yield and limits for the main visual parameters. Suffixes 075 and 05 indicate the lower 7.5th and 5th percentiles; (1) corrected to a reference depth of $150 \mathrm{~mm}$ according to EN 384(1996); (2) corrected to a reference moisture content of $12 \%$ according to EN 384 (1996); (3) adjusted for sample size according to EN 384 (1996); (4) fissures exceeding the maximum length established in prEN 14081-1 (2000) for strength classes above C18. (5) large defects
Tabelle 4 Charakteristische Festigkeits-, Steifigkeits- und Rohdichtewerte sowie Ausbeute in Abhängigkeit der Sortierparameter. Fußzeiger 075 und 05 bedeuten untere $7.5 \%$ and 5\%-Quantile; (1) Bezugshöhe 150 mm nach EN 384 (1996); (2) Bezugsfeuchte 12\% nach EN 384 (1996); (3) korrigiert für Stichprobenumfang nach EN 384 (1996); (4) Risse länger als Höchstwerte in prEN 14081-1 (2000) für Festigkeitsklassen über C18. (5) Große Fehlstellen

\begin{tabular}{|c|c|c|c|c|c|c|}
\hline & & $\begin{array}{l}\mathrm{f}_{\mathrm{m}, 075^{(1)}} \\
\mathrm{N} / \mathrm{mm}^{2}\end{array}$ & $\begin{array}{l}E_{\mathrm{m}, \mathrm{g} \cdot \mathrm{mean}} \\
\mathrm{N} / \mathrm{mm}^{2}\end{array}$ & $\begin{array}{l}\rho_{05}{ }^{(2)} \\
\mathrm{kg} / \mathrm{m}^{3}\end{array}$ & $\begin{array}{l}\rho_{\text {mean }}{ }^{(2)} \\
\mathrm{kg} / \mathrm{m}^{3}\end{array}$ & $\begin{array}{l}\text { Yield } n \\
(\%)\end{array}$ \\
\hline a) & All pieces & $25.3(22.8)^{(3)}$ & 12600 & 420 & 540 & 349 (100) \\
\hline b) & $\begin{array}{l}\text { Without pith } \\
\text { With pith }\end{array}$ & $\begin{array}{l}29.3(26.4)^{(3)} \\
22.1(19.2)^{(3)}\end{array}$ & $\begin{array}{l}13400 \\
11400\end{array}$ & $\begin{array}{l}426 \\
424\end{array}$ & $\begin{array}{l}554 \\
514\end{array}$ & $\begin{array}{l}223(64) \\
126(36)\end{array}$ \\
\hline c) & $\begin{array}{l}\text { Without pith, fiss. }{ }^{(4)} \text { and ld. } .^{(5)} \\
\text { Remainder }\end{array}$ & $\begin{array}{l}31.1(28.0)^{(3)} \\
21.6(19.0)^{(3)}\end{array}$ & $\begin{array}{l}13500 \\
11600\end{array}$ & $\begin{array}{l}427 \\
424\end{array}$ & $\begin{array}{l}557 \\
519\end{array}$ & $\begin{array}{l}190(54) \\
159(46)\end{array}$ \\
\hline d) & $\begin{array}{l}\text { Without pith, fiss. }{ }^{(4)} \text { and } 1 d .^{(5)} . K \leq 1 / 2 \\
\text { Without pith, fiss. }{ }^{(4)} \text { and ld. }{ }^{(5)} . K>1 / 2 \\
\text { Remainder }\end{array}$ & $\begin{array}{l}31.6(27.8)^{(3)} \\
28.8(21.6)^{(3)} \\
21.6(19.0)^{(3)}\end{array}$ & $\begin{array}{l}13700 \\
12300 \\
11600\end{array}$ & $\begin{array}{l}436 \\
386 \\
424\end{array}$ & $\begin{array}{l}554 \\
578 \\
519\end{array}$ & $\begin{aligned} 163 & (46) \\
27 & (8) \\
159 & (46)\end{aligned}$ \\
\hline e) & $\begin{array}{l}\text { Without pith, fiss. }{ }^{(4)} \text { and ld. }{ }^{(5)} . \mathrm{K} \leq 1 / 3 \\
\text { Without pith, fiss. }{ }^{(4)} \text { and ld. }{ }^{(5)} . \mathrm{K}>1 / 3 \\
\text { Remainder }\end{array}$ & $\begin{array}{l}32.7(28.1)^{(3)} \\
27.4(22.5)^{(3)} \\
21.6(19.0)^{(3)}\end{array}$ & $\begin{array}{l}13900 \\
12900 \\
11600\end{array}$ & $\begin{array}{l}431 \\
422 \\
424\end{array}$ & $\begin{array}{l}550 \\
569 \\
519\end{array}$ & $\begin{array}{r}119(34) \\
71(20) \\
159(46)\end{array}$ \\
\hline f) & $\begin{array}{l}\text { Without pith, fiss. }{ }^{(4)} \text { and ld. }{ }^{(5)} . K \leq 1 / 4 \\
\text { Without pith, fiss. }{ }^{(4)} \text { and ld. }{ }^{(5)} . K>1 / 4 \\
\text { Remainder }\end{array}$ & $\begin{array}{l}36.2(30.0)^{(3)} \\
28.6(24.3)^{(3)} \\
21.6(19.0)^{(3)}\end{array}$ & $\begin{array}{l}14500 \\
12900 \\
11600\end{array}$ & $\begin{array}{l}426 \\
426 \\
424\end{array}$ & $\begin{array}{l}556 \\
558 \\
519\end{array}$ & $\begin{array}{r}78(22) \\
112(32) \\
159(46)\end{array}$ \\
\hline g) & $\begin{array}{l}\text { Without pith, fiss. }{ }^{(4)} \text { and ld. }{ }^{(5)} . \mathrm{K} \leq 1 / 5 \\
\text { Without pith, fiss. }{ }^{(4)} \text { and ld. }{ }^{(5)} . \mathrm{K}>1 / 5 \\
\text { Remainder }\end{array}$ & $\begin{array}{l}36.4(29.1)^{(3)} \\
30.2(26.3)^{(3)} \\
21.6(19.0)^{(3)}\end{array}$ & $\begin{array}{l}14800 \\
13000 \\
11600\end{array}$ & $\begin{array}{l}418 \\
430 \\
424\end{array}$ & $\begin{array}{l}559 \\
556 \\
519\end{array}$ & $\begin{array}{r}55(16) \\
135(38) \\
159(46)\end{array}$ \\
\hline
\end{tabular}

to those of profile $b$ ), and the yield of the best grade decreases from $64 \%$ to $54 \%$.

Since knot ratio $(\mathrm{K})$ is considered after disregarding the specimens with pith, fissures exceeding the limits for strength classes above $\mathrm{C} 18$, and large defects, the relationship between $\mathrm{K}$ and bending strength was investigated for the pieces free of these characteristics, and a correlation coefficient of -0.40 was found, indicating a better relation than for the whole sample $(-0.32)$. A mean value of 0.30 and a standard deviation of 0.20 for $\mathrm{K}$, show a similar statistical distribution for specimens free of pith than for the whole sample as was presented in Table 2, and allow to analyse four options with limits for $\mathrm{K}$ ranging from $1 / 2$ to $1 / 5$, but maintaining without changes the grade of least quality.

Profile d) presents almost the same values for strength and MOE in the highest grade in comparison with profile c), but lower yield, with $27(8 \%)$ specimens in a second grade of lower quality than the first one. Profiles e), f) and g) show three options with increasing strength and MOE values for the first and second grades, and a balanced yield ranging from $34 \%$ to $16 \%$ and from $20 \%$ to $38 \%$ respectively. It is not possible to find density differences between the two best grades for practical purposes, whereas both exhibit also a low difference to the poorest grade.

It should be observed the high ratio of both MOE and strength to density for this timber species in comparison with the corresponding values for deciduous species according to EN 338 (1996), which may be an important advantage for structural purposes. In particular, the ratio of MOE to density is higher than the same ratio for all strength classes for deciduous species. These relationships appear to be in this case more similar to those found for poplar and, consequently, this particular feature accounts for the convenience of comparing bending strength, MOE and density values of this timber species with those corresponding to coniferous and poplar, even though it is necessary to determine the other additional properties. According to this, it is possible to assign the highest grade of profile f) to strength class $\mathrm{C} 30$ and the second one to $\mathrm{C} 24$, in both cases with balanced yield. The third grade values are greater than the corresponding for strength class $\mathrm{C} 18$, but the presence of quality reducing features, most of them associated with the presence of pith such as fissures, among others, may be a reason of rejection for structural purposes (Standards Australia 2000; European Committee for Standardization 2000).

Although characteristic values of bending strength, MOE and density allow to assign a grade/species/source combination to a strength class according to EN 338 (1996), and the other characteristic strength and stiffness properties can be calculated from those basic ones, specimens of Samples 6 and 7 were tested in tension and compression parallel to the grain, respectively, to check the relationships between these properties and the bending strength and stiffness. In order to avoid small groups the comparison is presented in Table 5 only for grades of profiles a), b) and c).

The influence of pith on tensile strength is greater than on the bending strength (see profile b), in line with results reported by Glos \& Lederer (2000) for a test series with 
Table 5 Bending strength and stiffness values for profiles a), b) and c) in comparison with the corresponding tension and compression ones (parallel to the grain). (1) Corrected to a reference depth/width of $150 \mathrm{~mm}$ according to EN 384 (1996); (2) corrected to a reference moisture content of $12 \%$ according to EN 384 (1996); (3) the lowest value for $n<20$
Tabelle 5 Biegefestigkeit und Biegesteifigkeit für Profile a), b) und c) im Vergleich mit den entsprechenden Werten für Druck und Zug. (1) Korrigiert für eine Bezugshöhe bzw. -breite von $150 \mathrm{~mm}$ nach EN 384 (1996); (2) Korrigiert für eine Holzfeuchte von 12\% nach EN 384 (1996); (3) der kleinste Wert für $\mathrm{n}<20$

\begin{tabular}{lllll}
\hline & & $\mathrm{f}_{\mathrm{m}, 075}{ }^{(1)} / \mathrm{E}_{\mathrm{m}, \mathrm{g}, \text { mean }}{ }^{(2)}$ & $\mathrm{f}_{\mathrm{t}, 0,05}{ }^{(1)} / \mathrm{E}_{\mathrm{t}, 0, \text { mean }}{ }^{(2)}$ & $\mathrm{f}_{\mathrm{c}, 0,05}{ }^{(2)} / \mathrm{E}_{\mathrm{c}, 0, \text { mean }}{ }^{(2)}$ \\
$\mathrm{N} / \mathrm{mm}^{2}$
\end{tabular}

beams and boards of beech in structural sizes. In contrast to tension, the influence of growth centre is rather poor on compression strength, exhibiting specimens free of pith values only $5 \%$ greater than those containing it. Interestingly, the modulus of elasticity in compression parallel to the grain shows the highest influence of pith, with a mean value $53 \%$ greater for the best grade than for the second one. The corresponding differences for tension and bending MOE are $22 \%$ and $17 \%$, respectively. Little influence of fissures on both tensile and compression properties is confirmed through the comparison of values corresponding to profiles b) and c), which is consistent with the criteria established in the American standard ASTM D 245 (1999).

Relationships of tensile to bending strength are 0.66 , $0.67,0.62,0.63$, and 0.67 , respectively, for the five grades presented in Table 5. These values are slightly higher than the one of 0.6 established in EN 384 (1996), and are not related to timber quality as was suggested by Burger \& Glos (1997) according to the results of an investigation involving timber of Picea abies from Central Europe. The Brazilian standard NBR 7190 (1997) assumes the same value for both tensile and bending strength obtained from tests on small clear specimens. Compression strength exhibits higher values than those corresponding to tensile and bending strength for this timber species. Since the presence of pith has a minor influence on compression strength, this difference increases for timber of lower quality. The results for compression strength are greater than those obtained from bending strength with the prescriptions of both European standard EN 384 (1996) and Brazilian standard NBR 7190 (1997), which establish $\mathrm{f}_{\mathrm{c}, 0}=5(\mathrm{f} \mathrm{m})^{0.45}$ and $\mathrm{f}_{\mathrm{c}, 0}=0.77 \mathrm{f}_{\mathrm{m}}$, respectively, in the last case on small clear specimens and three point bending. Burger \& Glos (1995) reported values for local MOE in bending (free of shear influence) 9\% higher than those for MOE in tension for European Spruce. However, Table 5 shows mean values of MOE in tension ranging from $2 \%$ to $7 \%$ greater than the corresponding global MOE in bending, which is more in line with the relation of $\mathrm{E}_{\mathrm{m}}=0.90 \mathrm{E}_{\mathrm{t}, 0}$ established by the Brazilian standard NBR 7190 (1997). The relation of bending to compression MOE presents values ranging from 0.66 to 0.86 , whereas

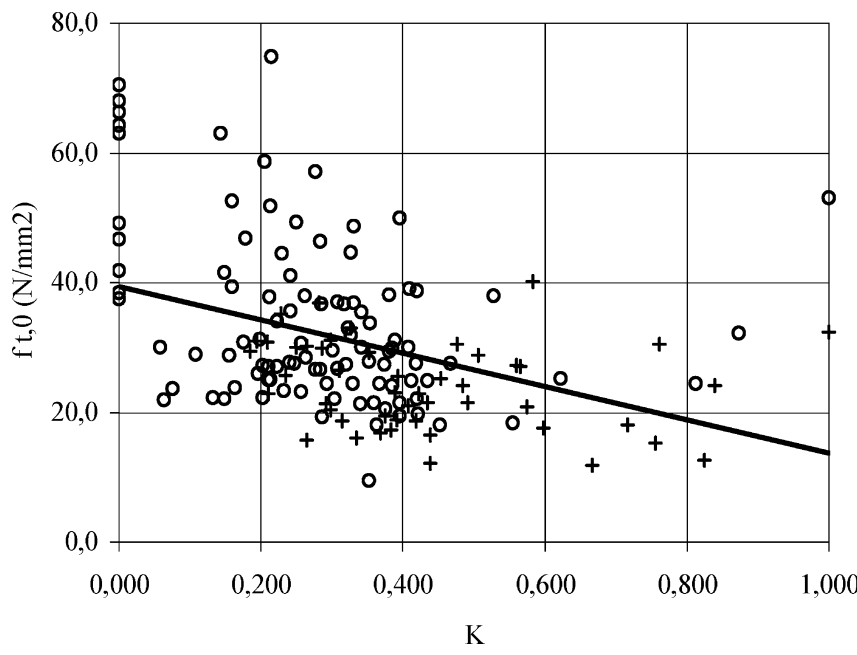

Fig. 2 Relationship between knot ratio (K) and tension strength for 150 specimens of Sample 6. Correlation coefficient $=-0.39$. Linear regression equation: $\mathrm{f}_{\mathrm{t} .0}=-25.6 \mathrm{~K}+39.3$. $(\bigcirc)$ : specimens free of pith; (+): specimens containing pith

Abb. 2 Zusammenhang zwischen Ästigkeit (K) und Zugfestigkeit für 150 Prüfkörper der Teilstichprobe 6. Korrelationskoeffizient $=-0.39$. Lineare Regressionsgleichung: $\mathrm{f}_{\mathrm{t} .0}=-25.6 \mathrm{~K}+39.3$. (○): Prüfkörper ohne Markröhre; (+): Prüfkörper mit Markröhre

the above mentioned Brazilian standard establishes $\mathrm{E}_{\mathrm{m}}=0.90 \mathrm{E}_{\mathrm{c}, 0}$.

Knot ratio is normally closer related to tensile strength than to the bending strength for both deciduous and coniferous species (Johansson et al. 1992; Glos 1995; Glos \& Lederer 2000). Figure 2 shows the relationship between $\mathrm{K}$ and tensile strength for Sample 6, and a correlation coefficient of -0.39 demonstrates a better relationship for tensile than for bending strength $(-0.32)$, although confirming a relatively poor influence of knot ratio on mechanical properties for this timber species, as was found for samples subjected to bending tests. This figure also shows the importance of pith as a reducing tensile-strength feature. 


\section{Conclusions}

It was possible to determine the influence of visual parameters on the mechanical properties of Argentinean Eucalyptus grandis through a test series with specimens in structural sizes subjected to bending, tension and compression parallel to the grain. A relatively poor relationship between knot ratio and bending as well as tensile strength was found in comparison with results reported for other timber species. In many cases it was impossible to distinguish the annual rings, and slope of grain exhibited very low values. These two features may therefore be disregarded as visual parameters for this case. The presence of pith, often associated with other defects as large fissures, significantly reduces bending and tensile strength and the modulus of elasticity in bending, tension and compression, but little influence was registered on compression strength. Bending strength, MOE and density profiles based on a simple visual strength-grading method were analysed, and high stiffness/density and strength/density relationships were found, which are similar to those corresponding to poplar and coniferous species. In particular, the ratio of MOE to density is higher than the same ratio for all strength classes for deciduous species according to EN 338 (1996). It is possible to assign a grade of good quality to strength class $\mathrm{C} 30$, a second one to $\mathrm{C} 24$, and the poorest one to C18 of the international system established in EN 338 (1996), even though it is necessary to determine the other additional properties. The relation between tensile and bending strength compares relatively well with the value of 0.6 established in EN 384 (1996) and exhibits no relation with timber quality, whereas mean values found for MOE in tension are slightly higher than the corresponding value for global modulus of elasticity in bending. Compression strength shows higher values than those corresponding to tensile and bending strength, mainly for timber of lower quality. Mean values found for $\mathrm{MOE}$ in compression parallel to the grain are also very high in comparison with the corresponding values in bending and tension parallel to the grain, exhibiting ratios of bending to compression MOE ranging from 0.66 to 0.86. The results obtained encourage further studies regarding the other strength and stiffness properties of this fast-growing Argentinean wood, which exhibits very good behaviour connected with the investigated values, and may therefore advantageously perform in solid as well as in glued laminated timber structures.

\section{References}

ABNT-Associaçao Brasileira de Normas Técnicas (1997) NBR 7190, Projeto de estructuras de Madeira. ABNT, Brasil

American Society for Testing and Materials (1999) ASTM D 24598, Standard practice for establishing structural grades and related allowable properties for visually graded lumber. ASTM, West Conshohocken, PA.

Burger N, Glos P (1997) Verhältnis von Zug- zu Biegefestigkeit bei Vollholz. Holz Roh- Werkstoff 55:345-350
Burger N, Glos P (1995) Verhältnis zwischen Zug- und BiegeElastizitätsmoduln von Vollholz. Holz Roh- Werkstoff 53:7374

Comité Europeo de Normalización (1997) UNE-EN 1310, Madera aserrada y madera en rollo. Método de medida de las singularidades. AENOR, Madrid

Dadswell H (1972) The anatomy of eucalypt woods. CSIRO Div Appl Chem Tech Pap No 66, Australia

Europäisches Komitee für Normung (1996) DIN EN 338, Bauholz für tragende Zwecke, Festigkeitsklassen. Beuth Verlag, Berlin

Europäisches Komitee für Normung (1996) DIN EN 384, Bauholz für tragende Zwecke, Bestimmung charakteristischer Festigkeits-, Steifigkeits- und Rohdichtewerte. Beuth Verlag, Berlin

Europäisches Komitee für Normung (1996) DIN EN 408, Holzbauwerke, Bauholz für tragende Zwecke und Brettschichtholz, Bestimmung einiger physikalischer und mechanischer Eigenschaften. Beuth Verlag, Berlin

Europäisches Komitee für Normung (1999) DIN EN 1194 , Holzbauwerke, Brettschichtholz, Festigkeitsklassen und Bestimmung charakteristischer Werte. Beuth Verlag, Berlin

European Committee for standardization (2000) Draft prEN 140811, Timber structures-strength graded structural timber with rectangular cross section-part 1: general requirements. CEN, Brussels

Glos P (1995) Strength grading. In: Timber Engineering STEP 1. Centrum Hout, The Netherlands, , pp A6/1-A6/8

Glos P, Diebold R (1987) Einfluß verschiedener Sortierbedingungen auf die Biegefestigkeit von Bauholz (Kantholz). Abschlußbericht 84510, Institut für Holzforschung, Universität München, München

Glos P, Lederer B (2000) Sortierung von Buchen- und Eichenschnittholz nach der Tragfähigkeit und Bestimmung der zugehörigen Festigkeits- und Steifigkeitskennwerte. Bericht Nr. 98508, Holzforschung, München

Glos P, Tratzmiller M (1996) Höherwertige Starkholznutzung durch verbesserte Einschnitt- und Sortierverfahren. Abschlußbericht 94506 an LWF, München

Hillis WE (1978) Wood quality and utilization. In: Hillis WE, Brown AG (eds) Eucalypts for wood production. CSIRO, Melbourne, pp 258-289

Hermoso Prieto E (2001) Caracterización mecánica de la madera estructural de Pynus sylvestris L.. Tesis Doctoral, Universidad Politécnica de Madrid, Escuela Técnica Superior de Ingenieros de Montes, Madrid

Hoffmeyer P. (1995) Wood as a building material. In: Timber Engineering STEP 1. Centrum Hout, The Netherlands, pp A4/ $1-\mathrm{A} 4 / 21$

INTA-Instituto Nacional de Tecnología Agropecuaria (1995) Manual para Productores de Eucaliptos de la Mesopotamia Argentina. Grupo Forestal, EEA INTA Concordia, Argentina

International Organization for Standardization (1975) ISO 31301975 (E), Wood-determination of moisture content for physical and mechanical tests

International Organization for Standardization (1975) ISO 31311975 (E), Wood-determination of density for physical and mechanical tests

Johansson CJ, Brundin J, Gruber R (1992) Stress grading of Swedish and German timber, a comparison of machine stress grading and three visual grading systems. SP Report 1992:23, Swedish National Testing and Research Institute, Sweden

Pérez del Castillo A (2001) Propiedades Mecánicas y Calidad de Madera de Eucalyptus Grandis del Norte de Uruguay. Informe de Investigación $\mathrm{N}^{\mathrm{o}} 4$, LATU, Montevideo

Standards Australia (1986) AS 2878-1986, Timber-classification into strength groups. Standards Australia, North Sydney, N.S.W.

Standards Australia (2000) AS 2082/2000, Timber-hardwoodvisually stress-graded for structural purposes. Standards Australia, Australia 